\title{
The Role of Bio-Fertilization in Improving Fruits Productivity-A Review
}

\author{
Walid Fediala Abd El-Gleel Mosa1,2*, Lidia Sas Paszt1', Nagwa A. Abd EL-Megeed ${ }^{3}$ \\ ${ }^{1}$ Research Institute of Horticulture, Konstytucji 3 Maja, Skierniewice, Poland \\ ${ }^{2}$ Plant Production Department, Faculty of Agriculture (Saba Basha), Alexandria University, Alexandria, Egypt \\ ${ }^{3}$ Nubaria Horticulture Research Station, Agriculture Research Center (ARC), Giza, Egypt \\ Email: "walidbreeder@yahoo.com
}

Received 15 September 2014; revised 15 October 2014; accepted 7 November 2014

Copyright (C) 2014 by authors and Scientific Research Publishing Inc.

This work is licensed under the Creative Commons Attribution International License (CC BY).

http://creativecommons.org/licenses/by/4.0/

cC) (i) Open Access

\begin{abstract}
Biofertilizers consist mainly of beneficial microorganisms that can release nutrients from raw materials and plant residues in the soil and make them available commercially where specific strains are used as biological fertilizers. They become recently, positive alternatives to chemical fertilizers because they help bring down the costs of chemical fertilizers especially $\mathbf{N}$ and $P$ and improve soil fertility by maintaining the physical properties of the soil. They may help in improving crop productivity and quality by increasing the biological $\mathbf{N}$ fixation, the availability and uptake of nutrients and stimulating the natural hormones. They are safe for humans, animals and environment and using them is accompanied with reducing the pollution occurring in our environment.
\end{abstract}

\section{Keywords}

Biofertilizers, Fruits Productivity, Arbuscular Mycorrhiza, Compost, Humus

\section{Introduction}

Continuous use of chemical fertilization leads to the deterioration of soil characteristics and fertility and might lead to the accumulation of heavy metals in plant tissues, affecting the fruit nutritional value and edibility [1]. Biological fertilization is based on the use of natural inputs including fertilizers, decaying remains of organic matter, excess crops, domestic sewage, animal manure, and microorganisms such as fungi and bacteria [2]. Applications of bio-fertilizers containing beneficial micro-organisms instead of synthetic chemicals are known to improve plant growth through the supply of plant nutrients and may help to sustain environmental health and

*Corresponding author. 
soil productivity [3]. They are known to improve fixation of nutrients in the rhizosphere, produce growth stimulants for plants, improve soil stability, provide biological control, biodegrade substances, recycle nutrients, promote mycorrhiza symbiosis, and develop bioremediation processes in soils contaminated with toxic, xenobiotic and recalcitrant substances [4]. Additionally, the use of bio-fertilizers can improve productivity per unit area in a relatively short time, consume smaller amounts of energy, mitigate contamination of soil and water, increase soil fertility, and promote antagonism and biological control of phytopathogenic organisms [5]. The great availability and release of N, P and K due to the application of biofertilizers were announced by [6] on olives, [7] on "volkamer" lemon seedlings, [8] on sweet oranges, [9] on avocados and mangos and [10] on bananas. Biofertilization is beneficial in stimulating growth and fruiting of pomes and stone fruits [11]. Biofertilizers are the most important for plant production and soil as they play an important role in improving fruit quality and yield grapevines [12]. Also, [13] showed that Mycrohyza and Phosphobacterium, Rhizobium and Azotobacter were favorable in improving nutritional status of trees, yield, physical and chemical properties of grapevines. [14] found that the use of biofertilizers gave a significant improvement of fruits of pomegranate in India as well as enhancing the rhizosphere microbial activity and concentration of various nutrients. [15] carried out an experiment to find out the effect of biofertilizers and inorganic fertilizers in "amrapali" mango trees. Three levels of inorganic fertilizers (100\% NPK, 75\% NPK and 50\% NPK) were applied alone and also in combination with different biofertilizers (Azotobacter, Azospirillum and vesiculararbuscular mycorrhiza) and they concluded that the treatments $100 \%$ NPK + Azotobacter + vesicular-arbuscular mycorrhiza and 75\% NPK + Azotobacter + vesicular-arbuscular mycorrhiza were effective and might be adopted to improve the vegetative growth and productivity with quality fruits.

Various organic sources (Farm yard manure ( $26 \mathrm{~kg} / \mathrm{plant} / \mathrm{vegetative} \mathrm{season),} \mathrm{poultry} \mathrm{manure}(10 \mathrm{~kg} / \mathrm{plant} /$ vegetative season), vermicompost (19 kg/plant/vegetative season) and neem cake ( $9 \mathrm{~kg} / \mathrm{plant} /$ vegetative season) along with various biofertilizer combinations (Azotobacter, Azospirillum, phosphorous solubilizers and potash mobilizers each at $100 \mathrm{~g} / \mathrm{plant} / \mathrm{vegetative} \mathrm{season)} \mathrm{were} \mathrm{tested} \mathrm{on} \mathrm{four-year-old} \mathrm{guava} \mathrm{cultivar} \mathrm{"Sardar"} \mathrm{to} \mathrm{study}$ their effects on growth, fruiting and yield. The results obtained showed higher fruit weight (230.5 and $224.8 \mathrm{~g}$ ) by application of neem cake and vermicompost + Azotobacter + phosphorous solubilizers + potash mobilizers. Maximum numbers of fruits producing per plant (626.3 fruits/plant) were found from plant fertilized with farm yard manure + Azotobacter + phosphorous solubilizers + potash mobilizers and caused maximum yield of 114 $\mathrm{kg} /$ plant as compared with $18.0 \mathrm{~kg}$ per plant in control. Treatment combinations with poultry manure + Azospirillum + phosphorous solubilizers + potash mobilizers showed the highest total soluble solids (12 Brix) and total sugar content of fruit (6.67\%), whereas the Vitamin C content (172.6 mg/100 g pulp) was recorded maximum by application of neem cake. So, it can be concluded that application of nutrients through organic along with biofertilizers improves soil health in terms of mean microbial population in the rhizosphere of root zone soil as compared with control [16].

\section{Arbuscular Mycorrhiza (AM)}

Mycorrhizas are mutualistic associations existing between fungi and most land plants. These partnerships are easy to locate in distinct places, from aquatic to desert habitats, occurring at different longitudes and latitudes [17]. Arbuscular mycorrhizal fungi (AMF) are obligate biotrophs, which can form mutualistic symbiosis with the roots of around $80 \%$ of plant species [18]. These mycorrhizal symbionts occur in almost all fruit tree species grown in the nursery or open field [19]. Arbuscular mycorrhizal fungi can establish extra radical mycelia, which disperse outside the roots to have access to a greater quantity of water and soil minerals for the host plants. The fungi receive plant carbohydrates for the completion of their life cycle [20]. [21] stated that vesicular-arbuscular species could supplement or replace chemical fertilizers of crops in varying environmental conditions. Arbuscular mycorrhizal (AM) associations have been shown to reduce damage caused by soil-borne plant pathogens. This prophylactic ability of arbuscular mycorrhizalfungi could be exploited in cooperation with other rhizospheric microbial antagonists to improve plant growth and health [22]. It is well documented that arbuscular mycorrhizasymbiosis can increase plant growth and nutrient uptake, improve fruit quality and alleviate several abiotic stresses such as low temperature stress, drought, salt stress, etc. [23].

Apple trees show a strong dependency on mycorrhizae [24], and in orchards they form symbiosis with the naturally occurring vesicular-arbuscular mycorrhizal (VAM) flora [25]. [26] reported a significant enhancement of banana plants as a result of dual inoculation of arbscular mycorrhizal fungi (AMF) and Azotobacter. [27] 
stated that a higher yield of fruits was harvested from plum and sour cherry trees inoculated with a mycorrhizal fungi. [28] mentioned that arbuscular mycorrhizas could improve growth performance and part nutrient acquisition of peach, which were absolutely dependent on arbscular mycorrhizal fungi species. On the other hand, some authors have reported a negative influence or lack of influence on plant productivity after mycorrhization [29].

\section{Compost}

Composting, generally defined as the biological aerobic transformation of an organic by-product into a different organic product that can be added to the soil without detrimental effects on crop growth [30]. It is one of the oldest techniques used for stabilizing natural wastes and biological fertilization of the soil. The main objective of this practice is to obtain a stable, chemically and biologically rich product with micro and macro nutrients [31].

The composting process can result in obtaining stable humus and humic and fulvic acids, characterized by a high nutritional value and potential for fertilization of soils with nutriment deficiencies [32]. The benefits provided by composts are broad and can be of a physical, chemical, biological, or environmental nature. Application of compost depends on the condition of the organic matter, moisture content, temperature, the $\mathrm{pH}$ and presence of microorganisms in the compost pile. For example, composts improve drainage and absorption of moisture in soils with structural deficiencies or lack of nutrients. They also make it possible to 1) increase crop productivity, 2) promote plant growth by incorporating essential nutrients, 3) facilitate implementation in different types of soil, 4) reduce runoff, and 5) obtain economic benefits for farmers [33]. Adding organic composts to apple orchard soils has been shown to improve the blooming and growth of newly planted trees [34] and fruit yields [35].

The annual applications using a high C:N compost source, like bark-chip amendments, can be beneficial for grapefruit production under a sound fertility management plan. Improved root growth and fruit yield were demonstrated using compost soil amendments applied under the tree canopy of flood irrigated "Rio Red" grapefruit trees. The overall agronomic importance of this research implies that annual additions of bark-chip compost to the soil surface on clay textured soils can lead to increases in soil organic matter that can modify soil physical properties and improving soil water content. This in turn may lead to citrus trees that can better handle period of droughts or tolerate fewer flood irrigation events when water resources become limited [36].

\section{Vermicompost}

Vermicomposts are finely-divided mature peat-like materials with a high porosity, aeration, drainage, and water-holding capacity and microbial activity, which are stabilized by interactions between earthworms and microorganisms in a non-thermophilic process [37]. Vermicomposts contain most nutrients in plant-available forms such as nitrates, phosphates, and exchangeable calcium and soluble potassium [38]. Vermicomposts have large particulate surface areas that provide many microsites for microbial activity and for strong retention of nutrients [39]. Also, they are rich in microbial populations and diversity, particularly fungi, bacteria and actinomycetes [38]. Vermicomposts contain plant growth regulators and other plant growth-influencing materials produced by microorganisms [40] including humates [41]. Vermicomposts also contain large amounts of humic substances [42] and some of the effects of these substances on plant growth have been shown to be very similar to the effects of soil-applied plant growth regulators or hormones [43].

Some studies have revealed that the positive effect of two kinds of vermicomposts on growth of strawberry plants is not influenced only by macronutrients availability, but also by the impact of plant growth regulators produced by microorganisms during the composting process [44].

\section{Humus}

Humic substances (HS) are recognized as a key component of soil fertility properties, since they control the chemical and biological properties of the rhizosphere [45]. According to some authors, humic substances present a random polymeric, amorphous structure formed by polyaromatic building blocks bridged to each other by ester, ether and C links, and carrying variable proportions of carboxyl, hydroxyl, amino and other hydrophilic groups [46]. Other authors support a new theory, which considers humic substances to be a supramolecular association of heterogeneous molecules held together by hydrophobic interactions and hydrogen bonds [47].

Since the 1980, it has been hypothesized that the positive effects of humic substances on plant metabolism 
may depend on the uptake of some macro- and micronutrients [48]. However, the hypothesis that they may interact with root cells by inducing endogenous activities, without being taken up by the plant, cannot be excluded. Furthermore, several studies have hypothesized that physiological mechanisms through which humic substances exert their effects may depend on hormones and, in particular, on the presence of auxin or auxin-like components in their structure [49].

Many literature data clearly showed a gradual increase in the yield parallel to increasing humic acid application [50] on peach, [51] and [52] on apricot, [53] and [54] on grape and [55] on "Le-Conte" pear. Also, [56] on "Grandnain" banana reported that increasing amount of humic acid markedly increased yield per feddan. [57] found that humic acid + compost + nitrogen fertilizers increased shoot length, shoot diameter, number of leaves/ foot, leaf area and fruit yield and weight of "Le-Conte" pear. Organic fertilization at high level plus humic acid enhanced naval orange vegetative growth by increasing trunk circumference, tree canopy volume, leaf area, total leaf chlorophyll content and leaves nutritional status through increasing their contents of nitrogen, phosphorus and potassium compared to the chemical fertilizers [58].

\section{Animal Manure}

Animal manure has been widely used for several decades by the farmers for soil fertilization, given low costs associated with its production, transportation, and processing. This wide availability and the nutritional intake of trace elements make it an attractive alternative for the development of fertilization on soils suffering nutritional deficiencies. Manure has many benefits [59], which include:

- It is a biological fertilizer with high proportions of nitrogen $(\mathrm{N})$ and potassium $(\mathrm{K})$, medium proportions of calcium $(\mathrm{Ca})$ and phosphorus $(\mathrm{P})$, and low proportions of magnesium $(\mathrm{Mg})$ and sulphur $(\mathrm{S})$. It makes it possible to obtain favourable effects on the physicochemical stability of soils, plant growth, and development of beneficial microbial populations.

- Manure adds organic matter to the soil.

- The level of organic solids is between $20 \%$ and $40 \%$.

- Given the high nitrogen content, decomposition of organic matter proceeds more quickly.

- Despite having a low phosphorus $(\mathrm{P})$ content, manure makes this element available to plants.

The application of manure to the soil must be made in quantities or concentrations acceptable by the rules and regulations of environmental and health authorities. In most cases, it is recommended that manure is spread in a thin layer over large portions of land, rather than stacked on a small portion [59]. Although animal manure provides improved availability of nutrients and facilitates plant growth, promote soil aeration, maximize the efficiency of agricultural production, and facilitate the development of biological activities that are able to create a medium rich in nutrients for plant growth, it also has disadvantages and limitations of particular interest. Some of these limitations referred to the possible risks to the safety of consumers, and to the physicochemical and biological stability of soils. In this regard, high levels of ammonia in manure can burn the foliage and roots of plants, increase the amount of weed flora, the costs associated with manure transportation, the presence of heavy metals (e.g. mercury, chromium, lead) poses a threat as a result of their carcinogenic potential and their capacity for bio-accumulation and bio-magnification in the food chain. For these reasons, the use of manure to fertilize soils should be well assessed and considered in order to evaluate the cost-benefit ratio. Finally, excessive application of manure can generate significant reductions in plants growth, extreme levels of nitrogen, ammonia, and salts that could lead to various undesirable scenarios for farmers and the soil itself [60].

[61] mentioned that organic manure improved vegetative growth and leaf mineral content of Washington navel orange. [62] found that applying different organic manures on "Anna" apple trees increased leaf macroelements (NPK) contents as compared with unfertilized trees.

\section{Tytanit ${ }^{\circledR}$}

Biostimulants are biologically active substances, which may contain e.g. hormones, proteins, and microelements [63], and their role is to improve plant growth and development. Titanium is considered to be a biostimulant [64]. It has been shown to have a beneficial effect on an increase in iron ion activity, enhancement pollengrain vigour, and an increase in the rate of nutrient uptake, as well as an improvement the health condition of plants [64] and positively influenced lipoxygenase activity [65]. Moreover, titanium limits the damage to plants caused by heavy metals [66]. In plants treated with titanium, high levels of chlorophyll and intensity of photosynthesis 
were observed [67]. Titanium may have a significant effect on the quality of the crops produced, e.g. increased amounts of ascorbic acid or calcium in plants [68]. [69] stated that Tytanit ${ }^{\circledR}$ had a positive influence on fruits quality and yielding on three fruiting repeating Polish raspberry cultivars: Pokusa, Polka and Poranna Rosa during years of 2005-2006 and it increased soluble solids content in fruits and reduced in Polka cv. Nitrates concentration. [70] mentioned that a single application of Tytanit ${ }^{\circledR}$ in the organic nursery seemed to be a sufficient treatment for improving the quality of maiden apple trees.

\section{By-Product}

Molasses, the noncrystallizable residue remaining after sucrose purification, has some advantages: it is a relatively inexpensive raw material, readily available, does not require starch hydrolysis and is already used for ethanol production [71].

The molasses obtained after sugar beet processing contains about $60 \%$ sucrose and $40 \%$ of other components. The nonsucrose substances include inorganic salts, raffinose, kestose, organic acids and nitrogen containing compounds. Molasses is used in the production of baker's yeast, in fermentation technology for ethanol, citric, lactic and gluconic acids production, as well as glycerol, butanol and acetone production, as an ingredient of mixed feeds or in the production of amino acids. Baker's yeast (Saccharomyces cerevisiae) is the preferred fermenting microorganism for ethanol production because of its superior and well-documented industrial performances. Other yeasts, referred to as nonconventional yeasts, have also been studied for ethanol production. Among them are those that endure much lower $\mathrm{pH}$ than the Saccharomyces species, such as Zygosaccharomyces sp., as well as those that perform ethanolic fermentation at temperatures above $40^{\circ} \mathrm{C}$, such as hansenula polymorpha [72].

\section{The Results Discussed in This Paper Allow Stating the Following Conclusions}

- Biological fertilization is economically efficient and sustainable alternative to standard NPK fertilization in fruits production.

- All the discussed products, arbuscular mycorrhiza, composting, vermicomposting, humus, animal manure, Tytanit $^{\circledR}$ and by-product, revealed a positive influence on vegetative growth and yielding of fruits trees.

- Due to successive effect of biological fertilization in fruits growing the most pronounced impact of biological products is observed after some years of their applications.

- Further field trails are needed to establish a proper doses and frequency of applications of biological products in fruits production in order to obtain the most beneficial influence on yield and its quality.

\section{Acknowledgements}

The work has been supported by the grant from the EU Regional Development Fund through the Polish Innovation Economy Operational Program, contract No. UDA-POIG. 01.03.01-10-109/08.

\section{References}

[1] Shimbo, S., Zhang, Z.W., Watanabe, T., Nakatsuka, H., Matsuda-Inoguch, N., Higashikawa, K. and Ikeda, M. (2001) Cadmium and Lead Contents in Rice and Other Cereal Products in Japan in 1998-2000. Science of the Total Environment, 281, 165-175. http://dx.doi.org/10.1016/S0048-9697(01)00844-0

[2] Chirinos, J., Leal, A. and Montilla, J. (2006) Use Alternative Biological Inputs for Sustainable Agriculture in the South of Anzoategui state. Applied and Interdisciplinary Sciences, Biotechnology. Digital Magazine Ceniap Today, 11, 1-7.

[3] O'Connell, P.F. (1992) Sustainable Agriculture-A Valid Alternative. Outlook on Agriculture, 21, 5-12.

[4] Rivera-Cruz, M., Trujillo, A., Córdova, G., Kohler, J., Caravaca, F. and Roldán, A. (2008) Poultry Manure and Banana Waste Are Effective Bio-Fertilizer Carriers for Promoting Plant Growth and Soil Sustainability in Banana Crops. Soil Biology and Biochemistry, 40, 3092-3095. http://dx.doi.org/10.1016/j.soilbio.2008.09.003

[5] Corpoica, Government of Antioquia and FAO (2007) Manual of Good Agricultural Practices in the Production of Climbing Bean. FAO, Medellín, 168 p.

[6] Ahmed, F.F. and El-Dawwey, G.M. (1992) Effect of Phosphorene (as a Source of Phosphate Dissolving Bacteria) in Enhancing Growth and Supplying of Chemlali Olive Seedling with Available Phosphorus. Minia Journal of Agricultural Research and Development, 14, 37-54. 
[7] Izquierdo, I., Lescaille, M., Sandrino, B., Garcia, M.J., Canizares, E., Azcuy, J., Rodriguez, M.E. and Gallardo, J.F. (1993) Effects of Biofertilizer Combinations on the Availability of Soil NPK to Volkameriana Citrus Seedlings. Proceedings of the 12th Latin American Congress of Soil Science, Salamanca, 26 September 1993, 711-719.

[8] Singh, C. and Sharma, B.B. (1993) Leaf Nutrient Composition of Sweet Orange as Affected by Combined Use of Bio and Chemical Fertilizers. South Indian Horticulture, 41, 131-134.

[9] Abd-Rabou, F.A. (2006) Effect of Microbien, Phosphorene and Effective Micro-Organisms (EM) as Bio-Stimulants on Growth of Avocado and Mango Seedlings. Egyptian Journal of Applied Sciences, 21, 673-693.

[10] Al-Ashkar, R.A., Mansour, A.E.M. and Merwad, M.M. (2007) Effect of Organic and Biofertilization Treatments on Growth and Productivity of Grandnian Banana Plants. Egyptian Journal of Applied Sciences, 22, 276-301.

[11] Von-Bennewitz, E. and Hlusek, J. (2006) Effect of the Application of Two Bio-Preparations on the Nutritional Status, Vegetative and Generative Behaviour of Jonagold Apple Trees. Acta Horticulturae, 721, 129-136.

[12] Akl, A.M., Ahmed, F.F., El-Morsy, F.M. and Ragab, M.A. (1997) The Effect of Soil and Foliar Application of Nitrogen, Phosphorus and Potassium on Some Vegetative and Fruiting Characteristics in White Banaty Seedless Grapevines. II Bud Behavior, Yield and Fruit Quality. Minia First Conference for Horticultural Crops, Minia, 19-21 October 1997, 453-476.

[13] El-Naggar, A.M.A. (2004) Effect of Organic Farming on Drip Irrigation Grapevine and Soil Chemical Properties. Proceeding of the 2nd International Conference of Agriculture, Nasr City, 25-27 March 2004, 117-128.

[14] Aseri, G.K., Jain, N., Panwar, J., Rao, A.V. and Meghwal, P.R. (2008) Biofertilizers Improve Plant Growth, Fruit Yield, Nutrition, Metabolism and Rhizosphere Enzyme Activities of Pomegranate (Punica granatum L.) in Indian Thar Desert. Scientia Horticulturae, 117, 130-135. http://dx.doi.org/10.1016/j.scienta.2008.03.014

[15] Kundu, S., Datta, P., Mishra, J., Rashmi, K. and Ghosh, B. (2011) Influence of Biofertilizer and Inorganic Fertilizer in Pruned Mango Orchard cv. Amrapali. Journal of Crop and Weed, 7, 100-103.

[16] Devi, H.L., Mitra, S.K. and Poi, S.C. (2012) Effect of Different Organic and Biofertilizer Sources on Guava (Psidium guajava L.) "Sardar". Acta Horticulturae, 959, 201-208.

[17] Guerra, B.E. (2008) Mycorrhiza arbuscular recurso microbiológico en la agricultura sostenible. Tecnología en Marcha, 21, 191-201.

[18] Giovannetti, M. (2008) Structure, Extent and Functional Significance of Belowground Arbuscular Mycorrhizal Networks. In: Varma, A., Ed., Mycorrhiza: State of the Art, Genetics and Molecular Biology, Eco-Function, Biotechnology, Eco-Physiology, Structure and Systematics, 3rd Edition, Springer-Verlag, Berlin Heidelberg, 59-72. http://dx.doi.org/10.1007/978-3-540-78826-3_3

[19] Calvet, C., Estaun, V., Camprubi, A., Hernandez-Dorrego, A., Pinochet, J. and Moreno, M.A. (2004) Aptitude for Mycorrhizal Root Colonization in Prunus Rootstocks. Scientia Horticulturae, 100, 39-49. http://dx.doi.org/10.1016/j.scienta.2003.08.001

[20] Nasim, G. (2010) The Role of Arbuscular Mycorrhizae in Inducing Resistance to Drought and Salinity Stress in Crops. In: Ashraf, M., Ozturk, M. and Ahmad, M.S.A., Eds., Plant Adaptation and Phytoremediation, Springer-Verlag, Berlin Heidelberg, 119-141. http://dx.doi.org/10.1007/978-90-481-9370-7_6

[21] Salinas, J.R., Díaz, A., Garza, E.Y. and Garza, I. (2005) Effects of Tillage and Biofertilization on the Soil Properties Affecting Sustainability of the Dry Bean Production. Food Science and Technology, 5, 30-34.

[22] Hause, B. and Fester, T. (2005) Molecular and Cell Biology of Arbuscular Mycorrhizal Symbiosis. Planta, 221, 184196. http://dx.doi.org/10.1007/s00425-004-1436-x

[23] Miransari, M. (2010) Contribution of Arbuscular Mycorrhizal Symbiosis to Plant Growth under Different Types of Soil Stress. Plant Biology, 12, 563-569.

[24] Koch, B.L., Covey, R.P. and Larsen, H.J. (1982) Response of Apple Seedlings in Fumigated Soil to Phosphorous and Vesicular-Arbuscular Mycorrhiza. HortScience, 17, 232-233.

[25] Dalpé, Y., Granger, R.L. and Furlan, V. (1986) Abondance relative et diversité des Endogonacées dans un sol de verger du Québec. Canadian Journal of Botany, 64, 912-917. http://dx.doi.org/10.1139/b86-122

[26] Ashokan, R., Sukhada, M. and Lalitha, A. (2000) Bio-Fertilizers and Bio-Pesticides for Horticultural Crops. Indian Journal of Horticulture, 45, 44-47.

[27] Swierczynski, S. and Stachowiak, A. (2010) The Influence of Mycorrhizal Fungi on the Growth and Yielding of Plum and Sour Cherry Trees. Journal of Fruit and Ornamental Plant Research, 18, 71-77.

[28] Wu, Q.S., Li, G.H. and Zou, Y.N. (2011) Roles of Arbuscular Mycorrhizal Fungi on Growth and Nutrient Acquisition of Peach (Prunus persica L. Batsch) Seedlings. The Journal of Animal and Plant Sciences, 21, 746-750.

[29] Corrêa, A., Strasser, R.J. and Martins-Loução, M.A. (2008) Response of Plants to Ectomycorrhizae in N-Limited Conditions: Which Factors Determine Its Variation? Mycorrhiza, 18, 413-427. 
$\underline{\text { http://dx.doi.org/10.1007/s00572-008-0195-0 }}$

[30] Eghball, B., Power, J.F., Gilley, J.E. and Doran, J.W. (1997) Nutrient, Carbon, and Mass Loss during Composting of Beef Cattle Feedlot Manure. Journal of Environmental Quality, 26, 189-193. http://dx.doi.org/10.2134/jeq1997.00472425002600010027x

[31] Coker, C. (2006) Environmental Remediation by Composting. Biocycle, 47, 18-23.

[32] Tognetti, C., Laos, F., Mazzarino, M.J. and Hernández, M.T. (2005) Composting vs. Vermicomposting: A Comparison of End Product Quality. Compost Science \& Utilization, 13, 6-13. http://dx.doi.org/10.1080/1065657X.2005.10702212

[33] Mills, T. (2006) Composting Cafeteria Residuals with Earthworm. Biocycle, 47, 54-55.

[34] Autio, W.R., Greene, D.W., Cooley, D.R. and Schupp, J.R. (1991) Improving the Growth of Newly Planted Apple Trees. HortScience, 26, 840-843.

[35] Niggli, U., Weibel, F.P. and Gut, W. (1990) Weed Control with Organic Mulch Materials in Orchards. Results from 8 Year Field Experiments. Acta Horticulturae, 285, 97-102.

[36] Nelson, S.D., Uckoo, R.M., Esquivel, H., Encisoz, J.M. and Jones, K. (2008) Compost Effects in "Rio Red" Grapefruit Production on a Heavy Textured Soil. Dynamic Soil, Dynamic Plant, 2, 67-71.

[37] Edwards, C.A. and Burrows, I. (1988) The Potential of Earthworm Composts as Plant Growth Media. In: Edwards, C.A. and Neuhauser, E., Eds., Earthworms in Waste and Environmental Management, SPB Academic Press, The Hague, 21-32.

[38] Edwards, C.A. (1998) Use of Earthworms in the Breakdown and Management of Organic Wastes. In: Edwards, C.A., Ed., Earthworm Ecology, Publications of the American Soil and Water Conservation Association, Boca Raton, 327354.

[39] Zhao, S.W. and Huang, F.Z. (1991) The Nitrogen Uptake Efficiency from 15 N Labelled Chemical Fertilizer in the Presence of Earthworm Manure. In: Veeresh, G.K., Rajagopal, D. and Viraktamath, C.A., Eds., Advances in Management and Conservation of Soil Fauna, Oxford and IBH Publishing Company, New Delhi, Bombay, 539-542.

[40] Tomati, U., Galli, E., Grapppelli, A. and Di Lena, G. (1990) Effect of Earthworm Casts on Protein Synthesis in Radish (Raphanus sativum) and Lettuce (Lactuca sativa) Seedlings. Biology and Fertility of Soils, 9, 288-289. http://dx.doi.org/10.1007/BF00634102

[41] Atiyeh, R.M., Arancon, N.Q., Edwards, C.A. and Metzger, J.D. (2002) The Influence of Earthworm-Processed Pig Manure on the Growth and Productivity of Marigolds. Bioresource Technology, 81, 103-108. http://dx.doi.org/10.1016/S0960-8524(01)00122-5

[42] Masciandaro, G., Ceccanti, B. and Garcia, C. (1997) Soil Agro-Ecological Management: Fertirrigation and Vermicompost Treatments. Bioresource Technology, 59, 199-206. http://dx.doi.org/10.1016/S0960-8524(96)00142-3

[43] Muscolo, A., Bovalo, F., Gionfriddo, F. and Nardi, S. (1999) Earthworm Humic Matter Produces Auxin-Like Effects on Daucus carota Cell Growth and Nitrate Metabolism. Soil Biology and Biochemistry, 31, 1303-1311. http://dx.doi.org/10.1016/S0038-0717(99)00049-8

[44] Arancon, N., Edwards, C., Bierman, P., Welch, C. and Metzger, J.D. (2004) Influences of Vermicomposts on Field Strawberries: Part 1. Effects on Growth and Yields. Bioresource Technology, 93, 145-153. http://dx.doi.org/10.1016/j.biortech.2003.10.014

[45] Nardi, S., Tosoni, M., Pizzeghello, D., Provenzano, M.R., Cilenti, A., Sturaro, A., Rella, R. and Vianello, A. (2005) Chemical Characteristics and Biological Activity of Organic Substances Extracted from Soils by Root Exudates. Soil Science Society of America Journal, 69, 2012-2019. http://dx.doi.org/10.2136/sssaj2004.0401

[46] Andreux, F. (1996) Humus in World Soils. In: Piccolo, A., Ed., Humic Substances in Terrestrial Ecosystems, Elsevier, Amsterdam, 45-100. http://dx.doi.org/10.1016/B978-044481516-3/50003-7

[47] Sutton, R. and Sposito, G. (2005) Molecular Structure in Soil Humic Substances: The New View. Environmental Science and Technology, 39, 9009-9015. http://dx.doi.org/10.1021/es050778q

[48] Pinton, R., Varanini, Z. and Nannipieri, P. (2007) The Rhizosphere: Biochemistry and Organic Substances at the SoilPlant Interface. 2nd Edition, CRC Press, Madison, 447. http://dx.doi.org/10.1201/9781420005585

[49] Nardi, S., Pizzeghello, D., Muscolo, A. and Vianello, A. (2002) Physiological Effects of Humic Substances on Higher Plants. Soil Biology and Biochemistry, Exeter, 34, 1527-1536. http://dx.doi.org/10.1016/S0038-0717(02)00174-8

[50] Fathi, M.A., Fawzia, M.E. and Yahia, M.M. (2002) Improving Growth, Yield and Fruit Quality of "Desert Red" Peach and "Anna" Apple by Using Some Biostimulants. Minia Journal of Agricultural Research and Development, 22, 519534.

[51] Eissa, F.M., Fathi, M.A. and Yehia, M.M. (2003) Response of "Canino" Apricot to Foliar Application of Some Biostimulants. Minia Journal of Agricultural Research and Development, 23, 69-82. 
[52] Shaddad, G., Khalil, A. and Fathi, M.A. (2005) Improving Growth, Yield and Fruit Quality of Canino Apricot by Using Bio, Mineral and Humate Fertilizers. Minufiya Journal of Agricultural Research, 30, 317-328.

[53] Omar, A.H. and Abdelall, A.H. (2005) Influence of Sulphuric Acid, Humic Acid, Sulphur and Irrigation Water on Growth and Productivity of "Superior Seedless" Vines Grown under Saline Condition. Journal of Agricultural Science, Mansoura University, 30, 6951-6961.

[54] Abbas, E.S., Bondok, S.A. and Girgis, V.H. (2006) Effect of Foliar with Some Nutrients and Humic Acid on Fruit Set, Yield and Quality of Roomy Ahmar Grapevines. Journal of Agricultural Science, Mansoura University, 31, 78477857.

[55] Ismail, A.F., Hussien, S.M., El-Shall, S.A. and Fathi, M.A. (2007) Effect of Irrigation Rate and Humic Acid on "Le-Cont" Pear. Journal of Agricultural Science, Mansoura University, 32, 7589-7603.

[56] El-Shenawi, M.R., Aly, H.S. and Mohamed, B.A.F. (2008) Response of "Grandnain” Banana to Humic Acid, Potassium and Magnesium Fertilization. Alexandria Science Exchange Journal, 29, 244-251.

[57] Salem, A.T., Fayed, T.A., Hagagg, L.F., Mahdy, H.A. and Alshall, S.A. (2010) Effect of Rootstocks, Organic Matter and Different Nitrogen Levels on Growth and Yield of "Le-Conte" Pear Trees. Journal of Horticultural Science and Ornamental Plants, 2, 130-147.

[58] Barakat, M.R., Yehia, T.A. and Sayed, B.M. (2012) Response of "Newhall" Naval Orange to Bio-Organic Fertilization under Newly Reclaimed Area Conditions I: Vegetative Growth and Nutritional Status. Journal of Horticultural Science \& Ornamental Plants, 4, 18-25.

[59] Luévano, A. and Velázquez, N.E. (2001) Singular Example in Agribusiness. Cattle Manure: Excellent Resource to Environmental Problems. Mexican Journal of Agribusiness, 5, 306-320.

[60] Carvajal-Muñoz, J.S. and Carmona-Garcia, C.E. (2012) Benefits and Limitations of Biofertilization in Agricultural Practices. Livestock Research for Rural Development, 24. http://www.lrrd.org/lrrd24/3/carv24043.htm

[61] Helail, B.M., Gobran, U.N. and Moustafa, M.H. (2003) Study on the Effect of Organic Manure Source, Method of Organic Manure Application and Bio-Fertilizers on Fruiting and Fruit Quality of Washington Navel Orange Trees. Egyptian Journal of Applied Sciences, 18, 297-320.

[62] Fayed, T.A. (2005) Effect of Some Organic Manure and Bio-Fertilizers on "Anna" Apple Trees. A. Vegetative Growth and Leaf Chemical Constituents. Egyptian Journal of Applied Sciences, 20, 159-175.

[63] Jankowski, K. and Dubis, B. (2008) Biostimulators in Plant Field Production. Mat. Conf. Biostimulators in Modern Plant Breeding. Plant Press, Warsaw, 24-25.

[64] Michalski, P. (2008) The Effect of Tytanit on the Yield Structure and the Fruit Size of Strawberry "Senga Sengana" and "Elsanta". Annales UMCS, Agricultura, 63, 109-118.

[65] Daood, H.G., Biacs, P., Fehér, M., Hajdu, F. and Pais, I. (1998) Effect of Titanium on the Activity of Lipoxygenase. Journal of Plant Nutrition, 11, 505-516. http://dx.doi.org/10.1080/01904168809363818

[66] Leskó, K., Stefanovits-Bányai, É., Pais, I. and Simon-Sarkadi, L. (2002) Effect of Cadmium and Titanium-Ascorbate Stress on Biological Active Compounds in Wheat Seed Lings. Journal of Plant Nutrition, 25, 2571-2581. http://dx.doi.org/10.1081/PLN-120014714

[67] Grenda, A. (2003) Tytanit aktywator procesów metabolicznych. Chemicals in Sustainable Agriculture, 4, $263-269$.

[68] Skupień, K. and Oszmiański, J. (2007) Influence of Titanium Treatment on Antioxidants Content and Antioxidant Activity of Strawberries. Acta Scientiarum Polonorum. Technologia Alimentaria, 6, 83-94.

[69] Grajkowski, J. and Ochmian, I. (2007) Influence of Three Biostymulants on Yielding and Fruit Quality of Three Primocane Raspberry Cultivars. Acta Scientiarum Polonorum: Hortorum Cultus, 6, 29-36.

[70] Grzyb, Z.S., Piotrowski, W., Bielicki, P. and Sas Paszt, L. (2012) Quality of Apple Maidens as Influenced by the Frequency of Application of Different Fertilizers in the Organic Nursery-Preliminary Results. Journal of Fruit and Ornamental Plant Research, 20, 41-49. http://dx.doi.org/10.2478/v10290-012-0014-8

[71] Sanchez, O.J. and Cardona, C.A. (2008) Trends in Biotechnological Production of Fuel Ethanol from Different Feedstocks. Bioresource Technology, 99, 5270-5295. http://dx.doi.org/10.1016/j.biortech.2007.11.013

[72] Satyanarayana, T. and Kunze, G. (2009) Yeast Biotechnology: Diversity and Applications. Springer, Berlin, 746. 
Scientific Research Publishing (SCIRP) is one of the largest Open Access journal publishers. It is currently publishing more than 200 open access, online, peer-reviewed journals covering a wide range of academic disciplines. SCIRP serves the worldwide academic communities and contributes to the progress and application of science with its publication.

Other selected journals from SCIRP are listed as below. Submit your manuscript to us via either submit@scirp.org or Online Submission Portal.
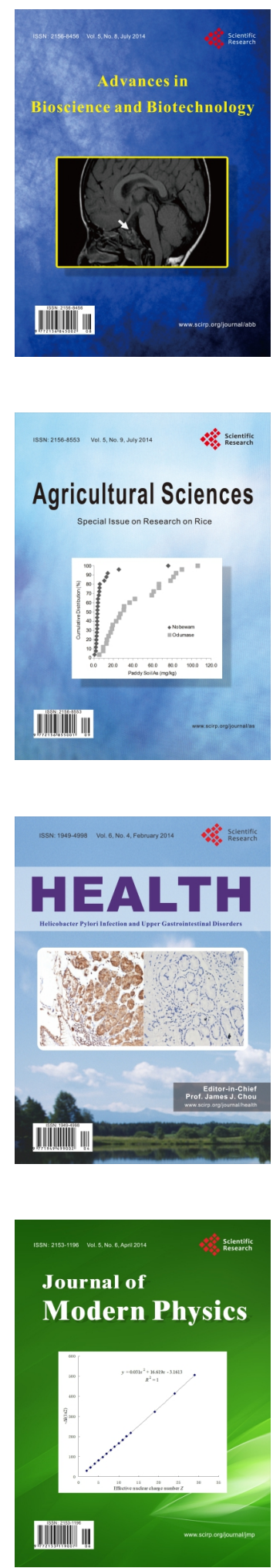
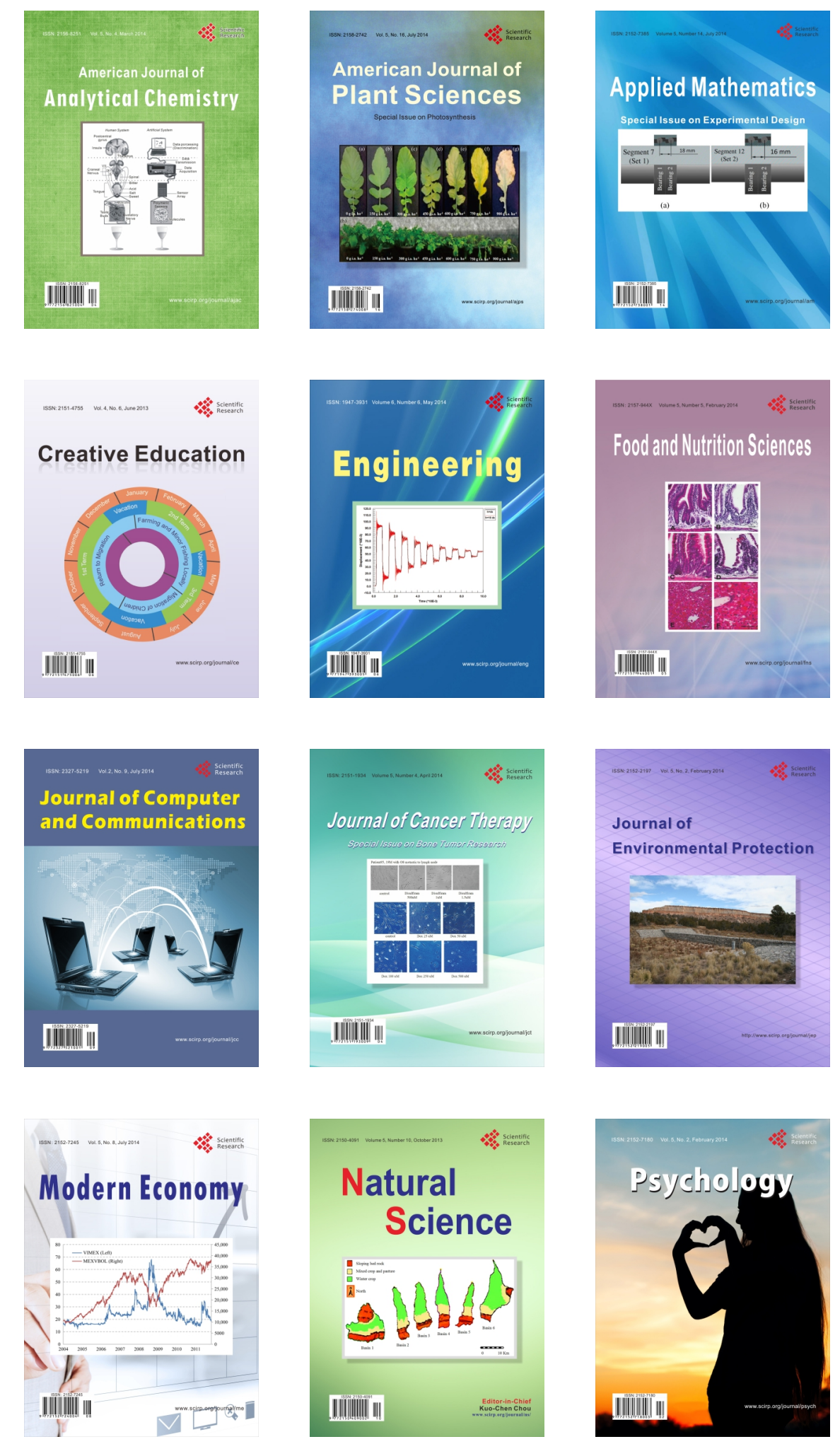